\title{
Gerak Robot Berkaki Dua menggunakan ROS dan RViz sebagai Visualisasi Interaktif
}

\author{
ADI SUCIPTO, RADEN SANGGAR DEWANTO, DADET PRAMADIHANTO
}

Teknik Elektro Politeknik Elektronika Negeri Surabaya, Indonesia

Email: adisucipto19950824@gmail.com

Received 22 Mei 2020 | Revised 18 Juni 2020 | Accepted 6 Juli 2020

\begin{abstract}
ABSTRAK
Pengembangan sistem operasi pada bidang robotika telah menjadi fokus utama pada era ini. Salah satu perkembangan sistem operasi pada teknologi robot saat ini adalah Robot Operating System (ROS) dengan RViz. ROS merupakan sistem operasi berbasis library dan beberapa tools untuk mengembangkan suatu program pada robot, sedangkan RViz merupakan visualisasi tiga dimensi yang dapat digunakan untuk memvisualisasikan robot dan data sensor dynamixel. Pada Penelitian kali ini, peneliti membuat simulasi beberapa gerakan yang dilakukan pada RViz dan kemudian diimplementasikan pada robot. Tingkat keberhasilan dari perencanaan gerakan ini memiliki rata rata error sebesar 1.8\%. Gerakan condong ke kiri memiliki rata-rata error sebesar $0.83 \%$. Gerakan condong ke kanan memiliki rata-rata error sebesar $0.84 \%$. Gerakan mengangkat satu kaki memiliki rata-rata error sebesar $1.71 \%$. Gerakan kaki kanan ke depan memiliki rata-rata error sebesar $3.83 \%$.
\end{abstract}

Kata kunci: Robot Berkaki Dua, Robot Operating System (ROS), RViz (rosvisualization), Dynamixel Controller, Data Sensor Dynamixel.

\begin{abstract}
The development of operating systems in the field of robotics has become the main focus of this era. One of the operating system developments in robot technology today is the Robot Operating System (ROS) with RViz. ROS is a library-based operating system and several tools for developing a program on robots, while RVIZ is a three-dimensional visualization that can be used to visualize robots and dynamixel sensor data. In this study, researchers made a simulation of some of the movements carried out on RViz and then implemented on robots. The success rate of planning this movement has an average error of $1.8 \%$. Leaning to the left has an average error of $0.83 \%$. Leaning to the right has an average error of $0.84 \%$. One leg lift has an average error of $1.71 \%$. The movement of the right foot forward has an average error of $3.83 \%$.
\end{abstract}

Keywords: Biped Robot, Robot Operating System (ROS), RViz (Ros-Visualization), Dynamixel Controller, Sensor Dynamixel Data. 


\section{PENDAHULUAN}

Perkembangan dunia robotika pada era revolusi industri 4.0 telah berkembang pesat. Salah satu perkembangan yang populer dilakukan saat ini adalah pembuatan sistem operasi pada robot. Beberapa pengembangan sistem operasi yang dikembangkan saat ini adalah robot operating sistem (Cashmore, dkk, 2015) Selain itu, beberapa software pendukung simulasi seperti V-REP juga dilakukan untuk mempermudah sistem pembuatan robot (Arfaq, dkk, 2018). Sistem tersebut dapat berupa perencanaan gerakan menggunakan algoritma dan metode tertentu (Suhendra, dkk, 2017). Akan tetapi robot operating sistem memiliki keunggulan yaitu dapat mensimulasikan semua keadaan lingkungan dengan lebih detail (Santos, dkk, 2013). Oleh karena itu, dibutuhkan sistem operasi yang dapat meringankan kinerja dalam pembuatan robot dengan tingkat kepresisian yang tinggi (Balakirsky, dkk, 2012). Sistem operasi yang digunakan pada penelitian kali ini adalah Robot operating system (ROS) dengan RViz sebagai media visualisasi interaktif. Penelitian yang dilakukan kali ini menggunakan robot berkaki dua dengan tujuan perencanaan gerakan robot. Ilustrasi dari salah satu perencanaan gerakan tersebut dapat dilihat pada Gambar 1 berikut.

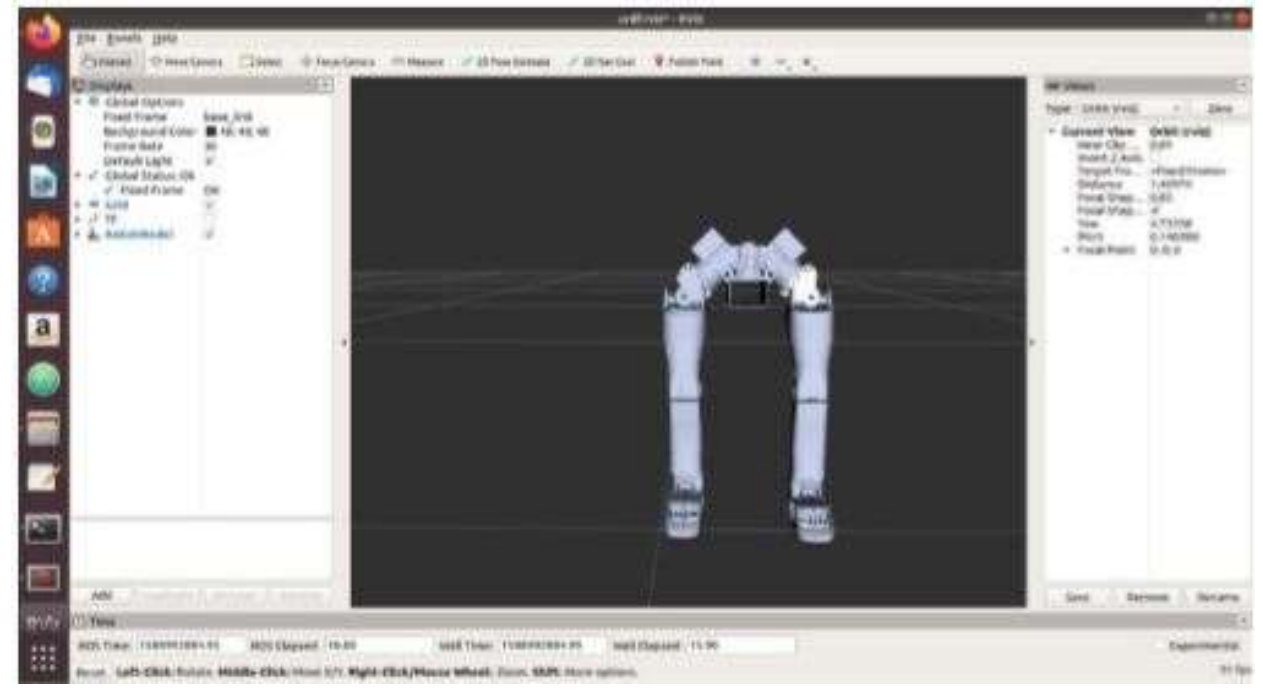

Gambar 1. Ilustrasi Robot Berkaki Dua Berdiri pada ROS Menggunakan RViz

Beberapa penelitian yang terkait dengan perencanaan gerak pada robot berkaki dua antara lain perancangan sistem kendali gerak lengan robot pengikut gerak lengan manusia berbasis mikrokontroller (Syafrudin, dkk, 2012). Penelitian lainnya adalah pengendalian robot line follower berbasis mikrokontroller AT-8535 menggunakan PID (Prabowo, dkk, 2013). Penggunaan perancangan dan pengendalian lengan robot dan line follower tersebutmenanda kan bahwa kurangnya efisien kinerja dari sistem robot yang menggunakan mikrokontroller.

Pengembangan sistem operasi menggunakan ROS juga telah dilakukan pada penelitian robot humanoid NimbRo-OP (Allgeuer, dkk, 2018). Penelitian tersebut mencangkup keseluruhan sistem yang diadaptasi pada robot menggunakan ROS. Penelitian yang serupa pada robot berkaki dua yaitu Darwin. Penelitian tersebut menggunakan ROS untuk melakukan sinergi pada aktuatornya (Cunha, dkk, 2016). Penelitian yang dilakukan kali ini mengadopsi dari jurnal yang membahas tentang sistem operasi pada robot antara lain Robot operating system (ROS) dan Gazebo sebagai media pembelajaran interaktif (Jalil, 2018). Selain itu, penelitian ini juga mengadopsi dari jurnal lain yang berjudul RViz: a toolkit for real domain data 
visualization (Kam, dkk, 2015) yang berfungsi sebagai visualisasi data pada model. Penelitian yang lain diadopsi untuk visualisasi adalah menggunakan gazebo (Takaya, dkk, 2016). Penelitian yang dilakukan saat ini menggunakan implementasi perencanaan gerak pada robot berkaki dua menggunakan ROS dan RViz sebagai media visualisasi interaktif. Pada penelitian ini dilakukan simulasi pada robot berkaki dua dengan melakukan beberapa gerakan. Gerakan tersebut adalah gerakan condong ke kanan, gerakan condong ke kiri, gerakan mengangkat satu kaki dan gerakan melangkahkan kaki ke depan. Pada simulasi tersebut digunakan ROS dan RViz untuk membangun perencanaan gerakan robot pada komputer. Hasil dari perencanaan tersebut kemudian diimplementasikan pada robot yang sesungguhnya.

\section{METODE PENELITIAN}

Penelitian yang digunakan kali ini menggunakan metode perencanaan gerak menggunakan robot operating sistem menggunakan RViz sebagai media visualisasi interaktif. Sebuah node yang berisi perintah menggerakkan model yang ada didalam RViz telah dirancang dan kemudian diimplementasikan pada robot dengan menggunakan feature dari beberapa packages.

ROS (Robot Operating Sistem)

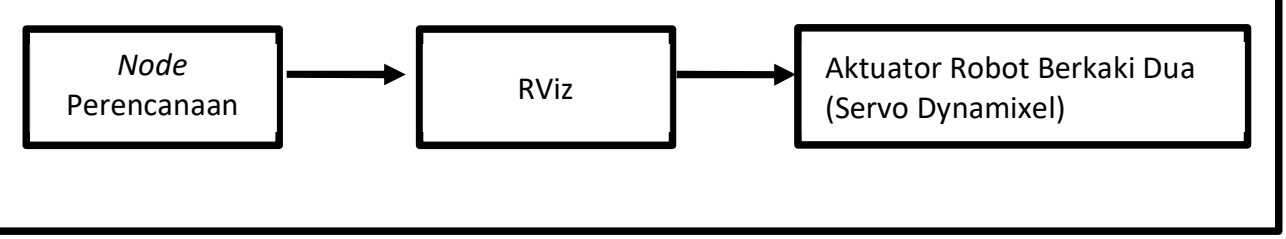

Gambar 2. Blok Diagram Sistem

Pada Gambar 2 dijelaskan bahwa perencanaan gerakan dibuat pada sebuah node. Node merupakan suatu aplikasi client pada sistem operasi yang terhubung dengan server ROS. Di dalam node ini dirancang rencana pergerakan dari masing-masing joint. Node tersebut kemudian dikirim pada media visualisasi yaitu RViz. Media visualisasi ini menampilkan gerakan dari robot berkaki dua sesuai dengan node yang telah dibuat.

\subsection{Perancangan Sistem Robot Berkaki Dua}

Perencanaan gerakan robot berkaki dua menggunakan ROS memiliki 2 sistem utama yaitu ROS Parameter Server dan ROS Node Client (Megalingam, dkk, 2018). Gambar 3 merupakan ilustrasi tentang hubungan kedua sistem tersebut untuk membentuk gerakan pada visualisasi dan robot sesungguhnya secara sama. Penelitian yang dilakukan kali ini menggunakan robot operating system (ROS) dengan menggunakan beberapa packages seperti dynamixe/ controller dan robot controller. Masing-masing packages tersebut memiliki node. Node tersebut kemudian dikirim pada media visualisasi yaitu RViz (Sokolov, dkk, 2016). Dalam pembuatan media visualisasi interaktif kali ini, digunakan tampilan model robot yang telah diatur pada packages urdf. 


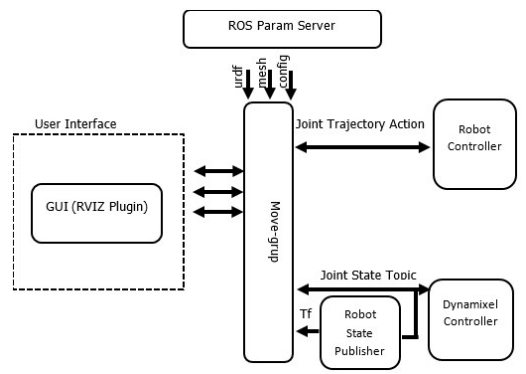

\section{Gambar 3. Perancangan Sistem pada ROS}

Pada Gambar 3 menunjukkan ros parameter server mengirimkan urdf, mesh dan config sebagai node yang berfungsi untuk menampilkan desain robot pada media visualisasi RViz. Dynamixel controller merupakan sebuah packagesyang berisi tentang library dari aktuator servo dynamixel. Packages ini dapat mengakses feature data sensor dynamixel. Feature tersebut dapat mengetahui kondisi aktuator seperti posisi, beban, temperature dan tegangan saat ini. Selain itu, pada packages ini berfungsi interface antara visualiasi RViz ke aktuator secara langsung. Sedangkan packages robot controller berfungsi untuk mengirimkan node dari program editor kepada RViz.

\subsection{Konfigurasi Robot Berkaki Dua}

Pada penelitian ini digunakan robot berkaki dua dengan 12 aktuator. Aktuator yang digunakan menggunakan servo dynamixe/ MX-106T. Aktuator jenis ini dapat memberikan feedback berupa posisi, temperature, beban dan tegangan input. Berikut merupakan konfigurasi dari robot berkaki dua tersebut:

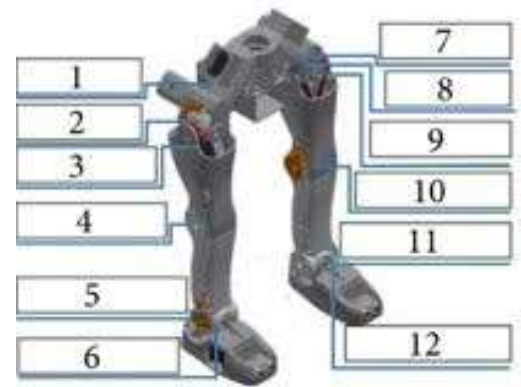

Keterangan :

1. Hip Yaw kanan 9. Hip Pitch Kiri

2. Hip Roll Kanan 10. Lutut Pitch Kiri

3. Hip Pitch Kanan 11. Engkel Pitch Kiri

4. Lutut Pitch Kanan 12. Engkel Roll Kiri

5. Engkel Pitch Kanan

6. Engkel Roll Kanan

7. Hip Yaw Kiri

8. Hip Roll Kiri

\section{Gambar 4. Konfigurasi Robot Berkaki Dua}

Pada Tabel 1 di bawah ini merupakan spesifikasi yang digunakan pada penelitian kali ini. Sistem operasi yang digunakan adalah robot operating system melodic, Ubuntu 18.04. Salah satu alasan digunakan ROS Melodic adalah ketersediaan library yang lengkap untuk mengakses aktuator servo dynamixe/ MX-106T. 
Tabel 1. Tabel Spesifikasi Robot

\begin{tabular}{|c|c|c|}
\hline No & Item & Spesifikasi \\
\hline & Mini-PC & Intel (R) Core (TM) i5-626OU CPU@1.80 Ghz \\
\hline 1. & Sistem operasi & Robot Operating Sistem Melodic, Ubuntu 18.04 \\
\hline 2. & Baterai & 3 cell @12.6V 5000 mAh \\
\hline & & ARM CORTEX-M3 (72 [MHz], 32 bit) \\
& Coreless (Maxon motor) \\
3. & Aktuator & Baud Rate: 8,000 [bps] $\sim 4.5[\mathrm{Mbps}]$ \\
& (Servo Dynamixe/MX-106T) & Torsi 8.4 [Nm] (pada 12 [V], 5.2 [A]) \\
& & Feature: Posisi, Temperatur, Beban, Tegangan \\
& & Input, dst. \\
\hline
\end{tabular}

\subsection{RViz sebagai Visualisasi Interaktif}

RViz merupakan visualisasi tiga dimensi yang dapat digunakan menampilkan robot pada program simulasi. Terdapat 2 sistem utama pada penelitian perencanaan gerakan robot ini. Sistem ini meliputi pengiriman node dengan pengaturan masing-masing sudut tiap joint pada RViz dan Pengiriman perintah pada aktuator servo dynamixel. Kedua sistem ini dapat divisualisasikan melalui RViz. Gambar 5 merupakan ilustrasi tentang hubungan kedua sistem tersebut untuk membentuk gerakan pada visualisasi dan robot sesungguhnya secara sama.

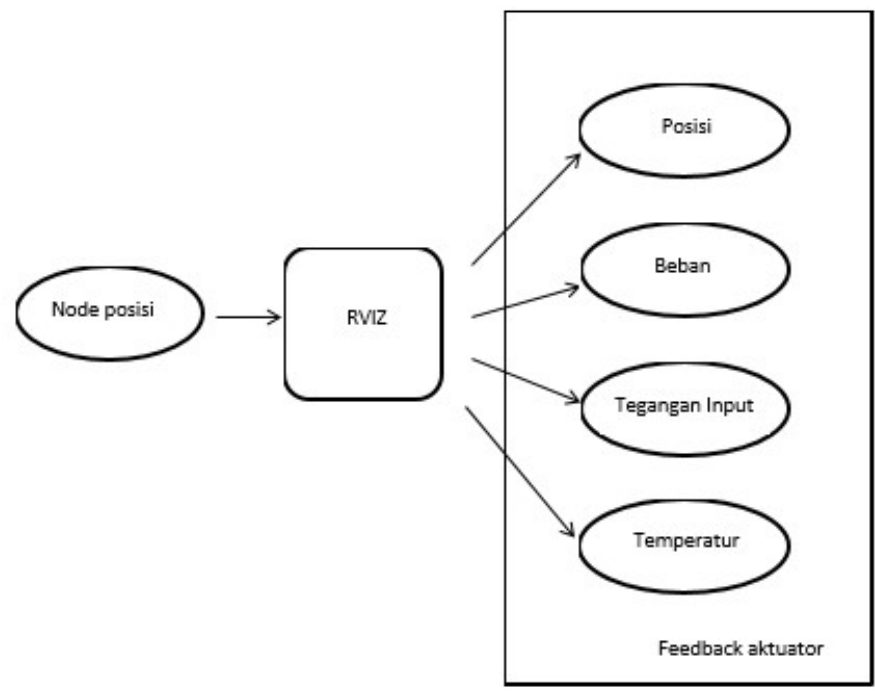

\section{Gambar 5. Ilustrasi Skema Pengiriman Node pada RViz dengan Aktuator}

Pada Gambar 5 menunjukkan bahwa RViz merupakan media visualisasi robot yang dapat menampilkan gerakan sesuai dengan pengaturan node yang telah dibuat. Isi dari node tersebut adalah pengaturan nilai-nilai sudut tiap joint yang kemudian dikirim sebagai perintah untuk menggerakkan visualisasi robot pada tampilan RViz. Media visualisasi ini menampilkan gerakan dari robot berkaki dua sesuai dengan node yang telah dibuat. Setelah node ini dijalankan, terdapat perintah rostopic yang berfungsi untuk menampilkan sistem pada ROS yang sedang berjalan. Rostopic yang digunakan pada penelitian ini bertujuan untuk mengetahui feedback dari aktuator seperti nilai posisi sudut, nilai beban, tegangan input dan temperature aktuator pada saat itu. 


\section{HASIL DAN PEMBAHASAN}

Tujuan dari penelitian kali ini adalah mencari nilai tingkat kepresisian dari ROS beserta RViz dengan kondisi robot yang sesungguhnya. Pada pengujian kali ini dilakukan simulasi pada robot berkaki dua dengan melakukan beberapa gerakan. Gerakan tersebut meliput gerakan condong ke kanan, gerakan condong ke kiri, gerakan mengangkat satu kaki dan gerakan kaki kanan robot ke depan. Pengaturan pemberian nilai sudut yang dikirimkan melalui nodeke RViz dengan cara menjalankan perintah rosrun yang terdapat pada ROS. Berikut ini pada Gambar 6 merupakan hasil running program pada terminal Ubuntu sebagai tanda pengiriman node untuk robot berdiri pada RViz telah dilakukan.

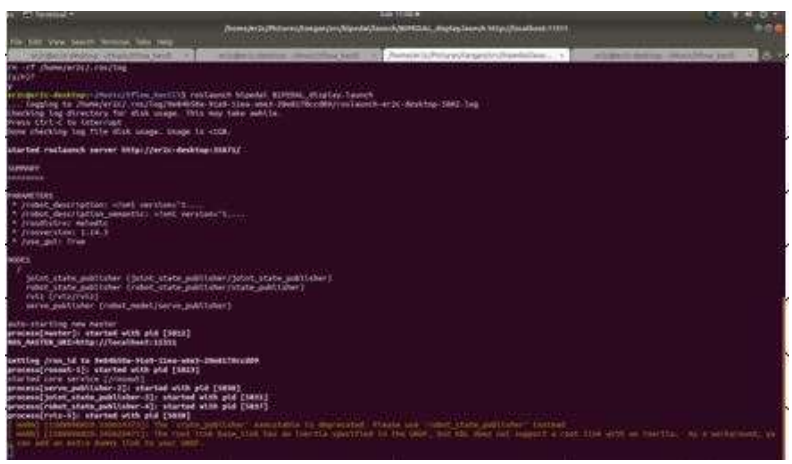

Gambar 6. Hasil Running Tampilan Program pada Terminal Ubuntu

Pada Gambar 6 tersebut menunjukkan bahwa ROS telah aktif dan beberapa node seperti servo_publisher, robot_state_publisher dan joint_state_publisher telah dijalankan. Node tersebut terdapat pada packages robot controller. Berikut ini merupakan hasil dari beberapa pengujian yang dilakukan dari node yang telah diatur nilai sudut dari posisi masing-masing joint:

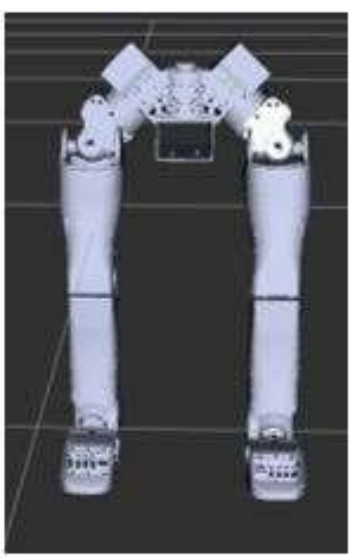

(a) Visualisasi Robot Berdiri

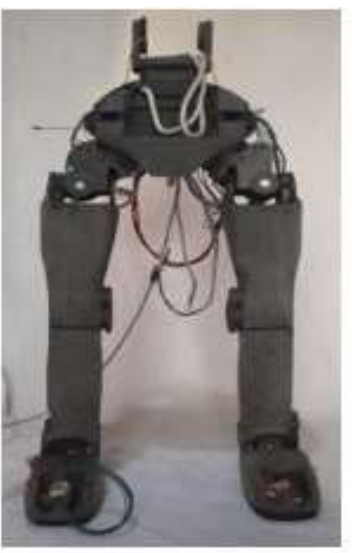

(b) Implementasi Robot Berdiri

\section{Gambar 7. Robot Kondisi Berdiri}

Pada Gambar 7(a) merupakan hasil visualisasi dari pengiriman node dengan pengaturan berdiri pada masing-masing joint. Pengaturan posisi ini dibuat dengan cara melakukan kalibrasi terlebih dahulu. Kalibrasi posisi berdiri robot didasarkan pada posture berdiri layaknya manusia. Kalibrasi tersebut dilakukan dengan cara mengatur posisi robot berdiri, kemudian digunakan packages dynamixel controller untuk membaca nilai posisi dari servo dynamixel tersebut. Setelah didapatkan nilai sudut dari posisi berdiri, nilai tersebut menjadi nilai acuan 
untuk melakukan perencanaan gerakanan selanjutnya. Pada Tabel 2 berikut ini merupakan hasil dari kalibrasi pembacaan nilai berdiri dari masing-masing aktuator.

\section{Tabel 2. Hasil Kalibrasi Nilai Resolusi Saat Robot Berdiri}

\begin{tabular}{|c|c|r|r|}
\hline No & Bagian Robot & Resolusi & Sudut $\left({ }^{\circ}\right)$ \\
\hline 1. & Hip Yaw Kanan & 2440 & 0 \\
\hline 2. & Hip rol/ Kanan & 1228 & 0 \\
\hline 3. & Hip Pitch Kanan & 1631 & 0 \\
\hline 4. & Lutut Pitch Kanan & 1076 & 0 \\
\hline 5. & Engkel Pitch Kanan & 674 & 0 \\
\hline 6. & Engkel Roll Kanan & 461 & 0 \\
\hline 7. & Hip Yaw Kiri & 1441 & 0 \\
\hline 8. & Hip rol/ Kiri & 3207 & 0 \\
\hline 9. & Hip Pitch Kiri & 3012 & 0 \\
\hline 10. & Lutut Pitch Kiri & 3690 & 0 \\
\hline 11. & Engkel Pitch Kiri & 970 & 0 \\
\hline 12. & Engkel Roll Kiri & 268 & 0 \\
\hline
\end{tabular}

Resolusi tersebut merupakan nilai satuan posisi yang terdapat pada data sensor dynamixel. Nilai satauan tersebut adalah 4096 untuk mewakili sudut $360^{\circ}$ (Robotis_MX-106T , 2020). Sedangkan pada Gambar 7(b) merupakan implementasi dari pengiriman node dari RViz menuju robot secara langsung. Implementasi tersebut menggunakan data dari RViz menggunakan packages robot controller dan kemudian dikirim ke aktuator menggunakan packages dynamixel controller. Nilai dari setiap resolusi yang didapat dari aktuator dynamixel digunakan sebagai titik acuan 0 dari robot.

Setelah mendapatkan kalibrasi berdiri robot, kemudian dilakukan perencanaan gerakan lainnya seperti condong ke kanan,condong ke kiri, mengkangkat satu kaki dan kaki kanan robot ke depan. Pada Gambar 8 berikut ini merupakan hasil dari simulasi visualisasi dan implementasi dari gerakan condong ke kiri pada robot:

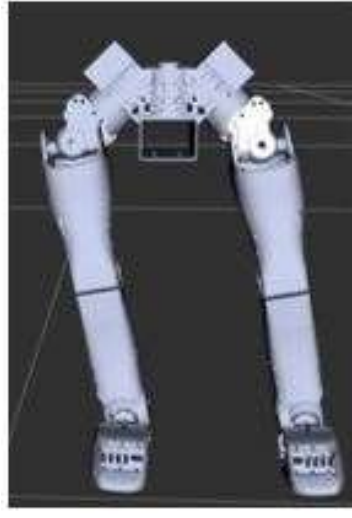

(a) Visualisasi Condong ke Kiri

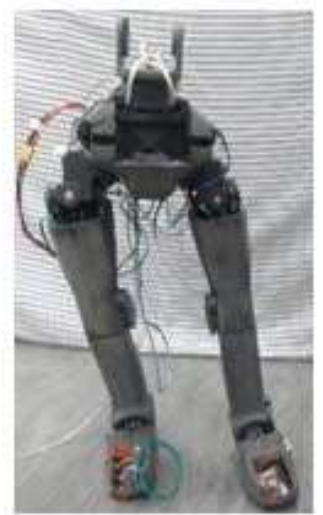

(b) Implementasi Condong ke Kiri (b) Implementas
Condong ke Kiri

Pada Gambar 8(a) merupakan visualisasi dari robot condong ke kiri yang ada di dalam RViz. Pemberian nilai-nilai sudut pada setiap join yang diberikan diatur pada node yang terdapat pada packages robot controller. Pembuatan posisi robot condong ke kiri, dilakukan dengan mengatur nilai pada bagian hip roll kanan dan hip roll kiri sebesar $25^{\circ}$. Sedangkan pada gambar 8(b) merupakan implementasi dari gerakan condong ke kiri. Pemberian nilai-nilai sudut 
pada aktuator ini didapatkan dari nilai yang diberikan pada RViz. Berikut merupakan tabel 3 yang menunjukkan nilai posisi sudut pada simulasi visualisasi pengiriman node dengan robot yang sudah diimplementasikan.

Tabel 3. Nilai Sudut pada Gerakan Robot Condong ke Kiri

\begin{tabular}{|c|c|c|c|c|}
\hline No & Bagian Robot & $\begin{array}{c}\text { Sudut Pada } \\
\text { Visualisasi }\left({ }^{\circ}\right)\end{array}$ & Sudut Pada Implementasi $\left({ }^{\circ}\right)$ & $\begin{array}{c}\text { Error } \\
(\%)\end{array}$ \\
\hline 1. & Hip Yaw Kanan & 0 & 0.625 & 0.9982 \\
\hline 2. & Hip rol/ Kanan & 25 & 25.14 & 0.0056 \\
\hline 3. & Hip Pitch Kanan & 0 & 0.877 & 0.9975 \\
\hline 4. & Lutut Pitch Kanan & 0 & 0.439 & 0.9987 \\
\hline 5. & Engkel Pitch Kanan & 0 & 0.275 & 0.9992 \\
\hline 6. & Engkel Roll Kanan & 0 & 0.375 & 0.9989 \\
\hline 7. & Hip Yaw Kiri & 0 & 0.352 & 0.9990 \\
\hline 8. & Hip rol/ Kiri & 25 & 24.94 & 0.0024 \\
\hline 9. & Hip Pitch Kiri & 0 & 0.439 & 0.9987 \\
\hline 10. & Lutut Pitch Kiri & 0 & 0.375 & 0.9989 \\
\hline 11. & Engkel Pitch Kiri & 0 & 0.439 & 0.9987 \\
\hline 12. & Engkel Roll Kiri & 0 & 0.352 & 0.9990 \\
\hline \multicolumn{4}{|c|}{ Rata-Rata Error } & 0.83 \\
\hline
\end{tabular}

Pada Tabel 3 menunjukkan nilai pengaturan sudut yang dilakukan pada media visualisasi dan implementasi. Dari perencanaan gerakan robot condong ke kiri, dibuat pengaturan sudut pada bagian joint hip rol/ kanan dan hip rol/ kiri (Gambar 4). Hal ini bertujuan untuk membuat pose dari robot berkaki dua menjadi condong kiri. Pada percobaan kali ini dilakukan pemberian nilai sudut $25^{\circ}$ pada bagian hip rol/ kanan dan hip rol/kiri. Proses pengukuran sudut implementasi robot dilakukan dengan cara membaca feedback posisi. Nilai error yang didapatkan untuk pengaturan gerakan robot condong ke kiri pada hip roll kiri adalah $0.0024 \%$. Sedangkan nilai error yang didapatkan untuk gerakan robot condong pada pada hip roll kanan adalah $0.0056 \%$. Sehingga didapatkan nilai error rata-rata pada gerakan ini sebesar $0.83 \%$. Pada Gambar 9 berikut ini merupakan grafik dari perubahan sudut gerakan condong ke kiri.

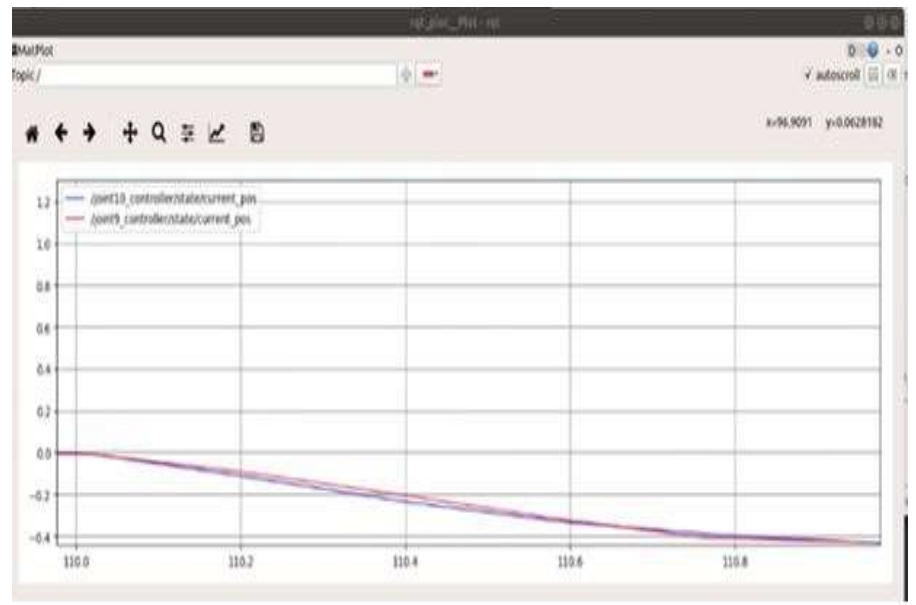

\section{Gambar 9. Grafik Perubahan Sudut Gerakan Condong ke Kiri}

Salah satu keunggulan menggunakan ROS adalah terdapat rqt_plot. Rqt_plot merupakan sebuah plugin yang dapat memvisualisasikan nilai numerik dalam plot 2D menggunakan backend plot yang berbeda. Pada Gambar 9 merupakan grafik yang menunjukkan perubahan 
sudut yang terbaca pada hip rol/ kanan dan hip rol/ kiri. Pada sumbu X menunjukkan respon terhadap waktu dan sumbu y merupakan nilai sudut dalam satuan radian. Grafik tersebut terlihat perubahan dari kondisi robot diam menjadi bergerak condong ke kiri $\left(1 \mathrm{rad}=57.29^{\circ}\right)$. Nilai pembacaan pada hip roll kanan adalah 0.4384 rad. Sedangkan nilai pembacaan pada hiproll kiri adalah 0.4352 rad. Pada Gambar 10 berikut merupakan gambar yang menunjukkan visualisasi dan implementasi gerakan robot condong ke kanan.

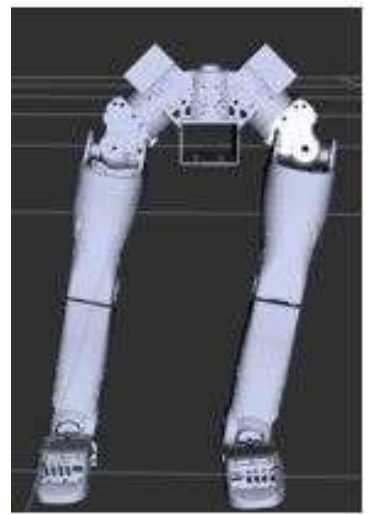

(a)Visualisasi Condong ke Kanan

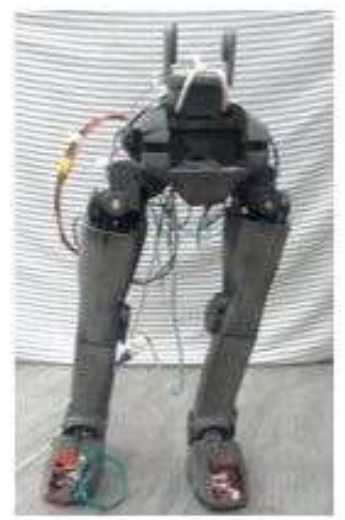

(b) Implementasi Condong ke Kanan (b) Implementasi

Pada Gambar 10(a) merupakan visualisasi dari robot condong ke kanan yang ada di dalam RViz. Pemberian nilai-nilai sudut pada setiap joint yang diberikan diatur pada node yang terdapat pada packages robot controller. Sedangkan pada Gambar 10(b) merupakan implementasi dari gerakan condong ke kanan. Pemberian nilai-nilai sudut pada aktuator ini didapatkan dari nilai yang diberikan pada RViz. Berikut merupakan Tabel 4 yang menunjukkan nilai posisi sudut pada simulasi visualisasi pengiriman node dengan robot yang sudah diimplementasikan.

Tabel 4. Nilai Sudut pada Gerakan Robot Condong ke Kanan

\begin{tabular}{|c|c|c|c|c|}
\hline No & Bagian Robot & $\begin{array}{c}\text { Sudut Pada } \\
\text { Visualisasi ( }{ }^{\circ} \text { ) }\end{array}$ & $\begin{array}{c}\text { Sudut Pada } \\
\text { Implementasi }\left({ }^{\circ}\right)\end{array}$ & Error (\%) \\
\hline 1. & Hip Yaw Kanan & 0 & 0.625 & 0.9982 \\
\hline 2. & Hip rol/ Kanan & -25 & -25.31 & 0.0120 \\
\hline 3. & Hip Pitch Kanan & 0 & 0.877 & 0.9975 \\
\hline 4. & Lutut Pitch Kanan & 0 & 0.439 & 0.9975 \\
\hline 5. & Engkel Pitch Kanan & 0 & 0.275 & 0.9992 \\
\hline 6. & Engkel Roll Kanan & 0 & 0.375 & 0.9989 \\
\hline 7. & Hip Yaw Kiri & 0 & 0.352 & 0.9990 \\
\hline 8. & Hip rol/ Kiri & -25 & -24.53 & 0.0188 \\
\hline 9. & Hip Pitch Kiri & 0 & 0.439 & 0.9987 \\
\hline 10. & Lutut Pitch Kiri & 0 & 0.375 & 0.9895 \\
\hline 11. & Engkel Pitch Kiri & 0 & 0.439 & 0.9987 \\
\hline 12. & Engkel Roll Kiri & 0 & 0.352 & 0.9990 \\
\hline \multicolumn{7}{r}{} & Rata-Rata Error & \\
\hline
\end{tabular}

Pada Tabel 4 menunjukkan nilai pengaturan sudut yang dilakukan pada media visualisasi dan implementasi. Dari perencanaan gerakan robot condong ke kiri, dibuat pengaturan sudut pada bagian joint hip rol/ kanan dan hip rol/ kiri (Gambar 4). Hal ini bertujuan untuk membuat pose dari robot berkaki dua menjadi condong kiri. Pada percobaan kali ini dilakukan pemberian nilai 
sudut $-25^{\circ}$ pada bagian hip rol/ kanan dan hip rol/ kiri. Nilai (-) menunjukkan arah perputaran motor searah dengan jarum jam. Proses pengukuran sudut implementasi robot dilakukan dengan cara membaca feedback posisi. Nilai error yang didapatkan untuk pengaturan gerakan robot condong ke kiri pada hip rol/ kiri adalah $0.0188 \%$. Sedangkan nilai error yang didapatkan untuk gerakan robot condong pada pada hip rol/ kanan adalah $0.012 \%$. Sehingga didapatkan nilai error rata-rata pada gerakan ini sebesar $0.84 \%$. Pada Gambar 11 berikut ini merupakan grafik dari perubahan sudut gerakan condong ke kanan:

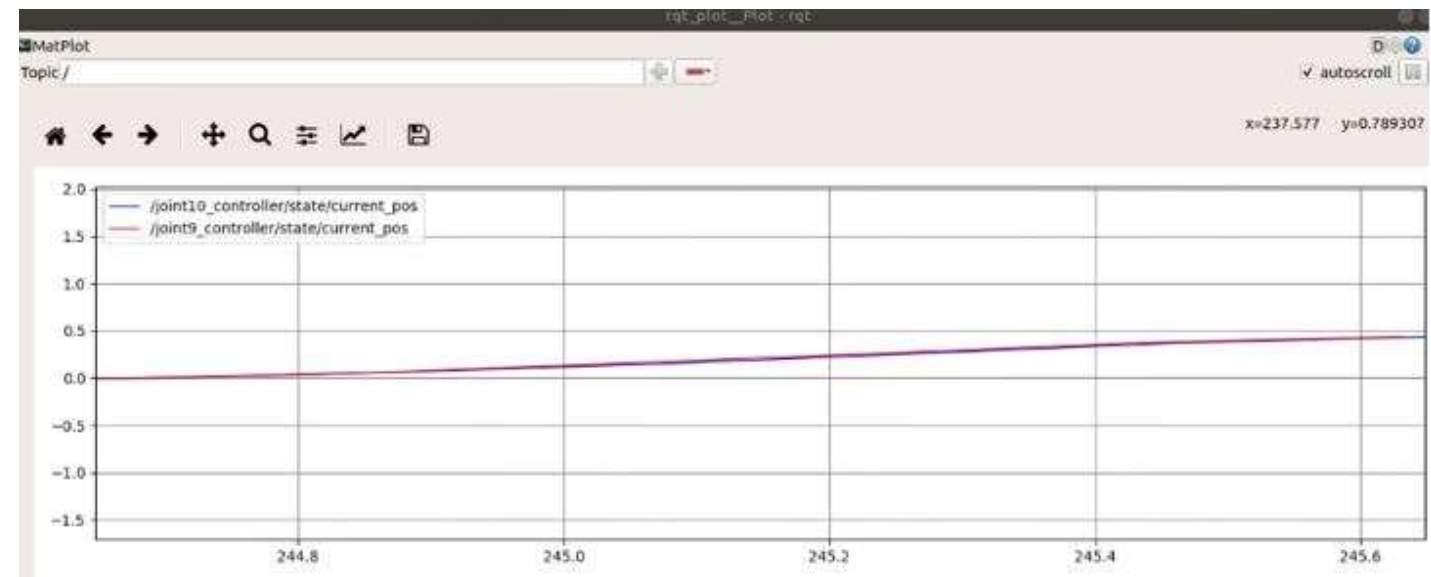

Gambar 11. Grafik Perubahan Sudut Gerakan Condong ke Kanan

Pada Gambar 11 merupakan grafik yang menunjukkan perubahan sudut yang terbaca pada hip roll kanan dan hip rol/ kiri. Pada sumbu X menunjukkan respon terhadap waktu dan sumbu y merupakan nilai sudut dalam satuan radian. Grafik tersebut terlihat perubahan dari kondisi robot diam menjadi bergerak condong ke kanan $\left(1 \mathrm{rad}=57.29^{\circ}\right)$. Nilai pembacaan pada hip rol/ kanan adalah 0.4417 rad. Sedangkan nilai pembacaan pada hiproll kiri adalah 0.4281 rad. Pada Gambar 12 berikut merupakan gambar yang menunjukkan visualisasi dan implementasi gerakan robot mengangkat satu kaki:

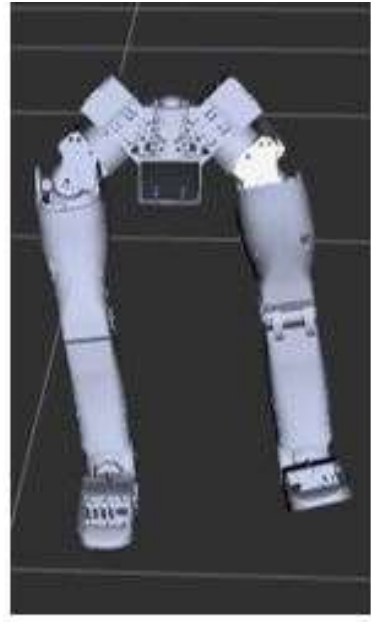

(a) Visualisasi Mengangkat Satu Kaki $\begin{array}{ll}\text { (b) Implementasi Menga } & \\ \text { Gambar 12. Kondisi Robot Mengangkat Satu Kaki }\end{array}$

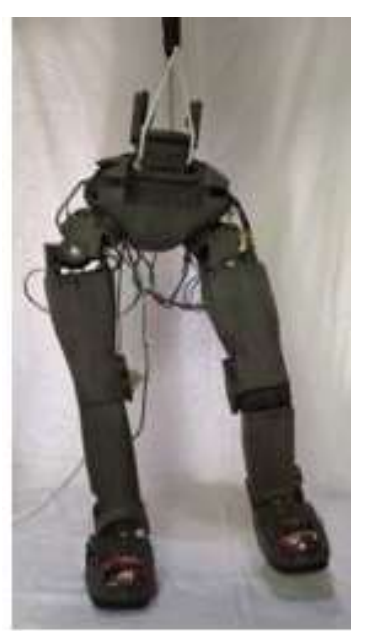

(b) Implementasi Mengangkat Satu Kaki

Pada Gambar 12(a) merupakan visualisasi dari robot mengangkat satu kaki yang ada di dalam RViz. Pemberian nilai-nilai sudut pada setiap join yang diberikan diatur pada node yang 
terdapat pada packages robot controller. Sedangkan pada Gambar 12(b) merupakan implementasi dari gerakan robot mengangkat satu kaki. Pemberian nilai-nilai sudut pada aktuator ini didapatkan dari nilai yang diberikan pada RViz. Berikut merupakan Tabel 5 yang menunjukkan nilai posisi sudut pada simulasi visualisasi pengiriman node dengan robot yang sudah diimplementasikan.

Tabel 5. Nilai Sudut pada Gerakan Robot Angkat Satu Kaki

\begin{tabular}{|c|c|c|c|c|}
\hline No & Bagian Robot & $\begin{array}{c}\text { Sudut Pada } \\
\text { Visualisasi } \\
\left({ }^{\circ}\right)\end{array}$ & $\begin{array}{c}\text { Sudut Pada } \\
\text { Implementasi } \\
\left({ }^{\circ}\right)\end{array}$ & $\begin{array}{c}\text { Error } \\
(\mathbf{\%})\end{array}$ \\
\hline 1. & Hip Yaw Kanan & 0 & 0.0878 & 0.9975 \\
\hline 2. & Hip rol/ Kanan & 10 & 10.2832 & 2.8320 \\
\hline 3. & Hip Pitch Kanan & 0 & 0.0878 & 0.9975 \\
\hline 4. & Lutut Pitch Kanan & 10 & 10.4062 & 4.0625 \\
\hline 5. & Engkel Pitch Kanan & 10 & 9.7273 & 2.7265 \\
\hline 6. & Engkel Roll Kanan & 0 & 0.8789 & 0.9975 \\
\hline 7. & Hip Yaw Kiri & 0 & 0.8789 & 0.9975 \\
\hline 8. & Hip rol/ Kiri & 10 & 10.2832 & 2.8320 \\
\hline 9. & Hip Pitch Kiri & 45 & 44.8760 & 0.2753 \\
\hline 10. & Lutut Pitch Kiri & 45 & 45.3109 & 0.6909 \\
\hline 11. & Engkel Pitch Kiri & 10 & 9.7832 & 2.1679 \\
\hline 12. & Engkel Roll Kiri & 0 & 0.8789 & 0.9975 \\
\hline \multicolumn{7}{|c|}{ Rata-Rata Error } & \\
\hline
\end{tabular}

Pada Tabel 5 menunjukkan nilai pengaturan sudut yang dilakukan pada media visualisasi dan implementasi dari perencanaan gerakan robot mengangkat satu kaki, dibuat pengaturan sudut pada bagian joint hip rol/ kanan dan hip rol/kiri (Gambar 4). Hal ini bertujuan untuk membuat pose dari robot berkaki mengangkat satu kaki. Pada percobaan kali ini dilakukan pemberian nilai sudut $10^{\circ}$ pada bagian hip roll kanan. Nilai error yang muncul antara visualisasi dan implementasi pada bagian ini adalah $2.83 \%$. Nilai error yang muncul pada pemberian $10^{\circ}$ lutut pitch kanan adalah $4.06 \%$. Nilai error yang muncul pada pemberian $10^{\circ}$ engkel picth kanan adalah $2.72 \%$. Nilai error yang muncul pada pemberian $45^{\circ}$ hip pitch kiri adalah $0.27 \%$. Nilai error yang muncul pada pemberian $45^{\circ}$ lutut pitch kiri adalah $0.69 \%$. Proses pengukuran sudut implementasi robot dilakukan dengan cara membaca feedback posisi. Perbedaan pembacaan nilai implementasi $0^{\circ}$ pada aktuator disebabkan karena factor mekanik seperti backlash pada servo. Sehingga didapatkan nilai error rata-rata pada gerakan ini sebesar $1.71 \%$. Pada Gambar 13 berikut ini merupakan grafik dari perubahan sudut gerakan angkat satu kaki.

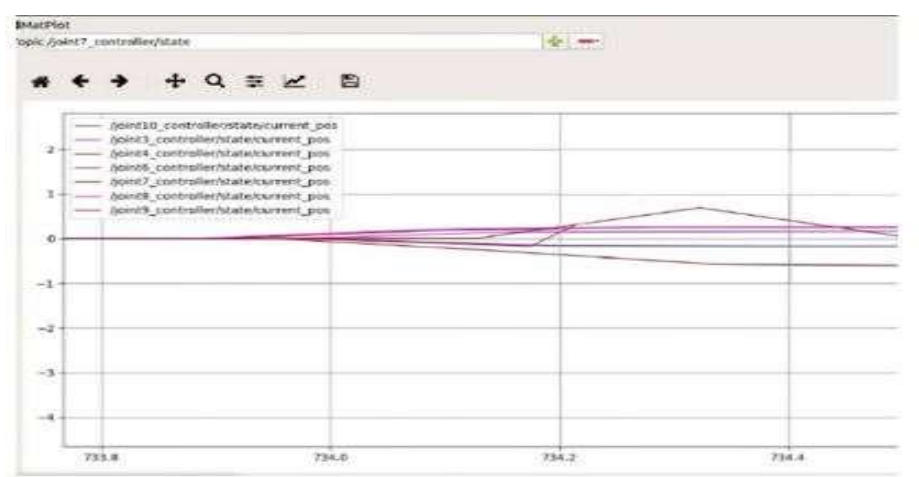

Gambar 13. Grafik Perubahan Sudut Gerakan Angkat Satu Kaki 
Pada Gambar 13 merupakan grafik yang menunjukkan perubahan sudut yang terbaca pada hip roll kanan, hip rol/ kiri, engkel pitch kanan, lutut pitch kanan, hip pitch kiri, engkel pitch kiri dan lutut pitch kiri. Pada sumbu $X$ menunjukkan respon terhadap waktu dan sumbu y merupakan nilai sudut dalam satuan radian. Grafik tersebut terlihat perubahan dari kondisi robot diam menjadi bergerak condong ke kiri $\left(1 \mathrm{rad}=57.29^{\circ}\right)$. Nilai pembacaan pada hip pitch kiri adalah 0.78 rad. Sedangkan nilai pembacaan pada lutut pitch kiri adalah 0.79 rad.

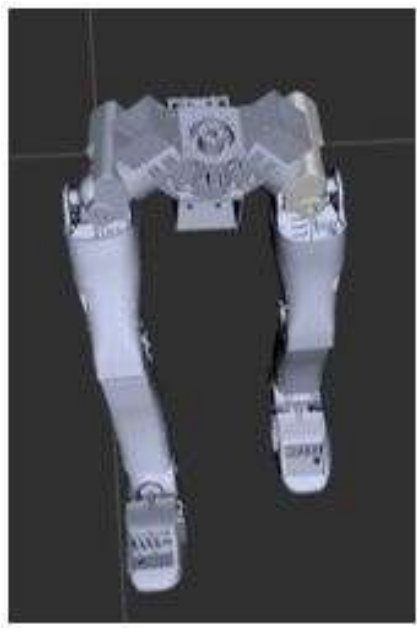

(a) Visualisasi Kaki Kanan ke Depan

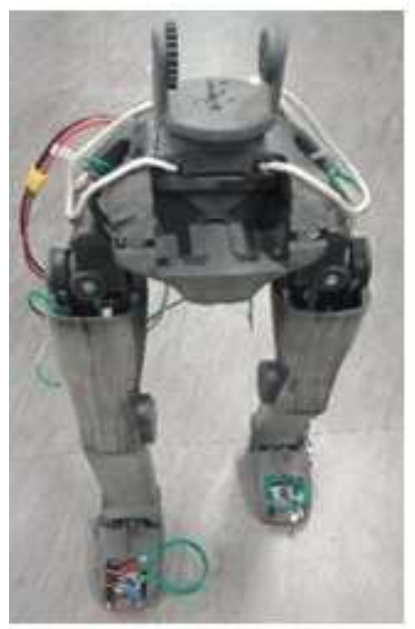

(b) Implementasi Kaki Kanan ke Depan Gambar 14. Kondisi Kaki Kanan Robot ke Depan

Pada Gambar 14(a) merupakan visualisasi dari kaki kanan robot ke depan yang ada di dalam RViz. Pemberian nilai-nilai sudut pada setiap joint yang diberikan diatur pada node yang terdapat pada packages robot controller. Sedangkan pada Gambar 14(b) merupakan implementasi dari kaki kanan robot ke depan. Pemberian nilai-nilai sudut pada aktuator ini didapatkan dari nilai yang diberikan pada RViz. Berikut merupakan Tabel 5 yang menunjukkan nilai posisi sudut pada simulasi visualisasi pengiriman node dengan robot yang sudah diimplementasikan.

Tabel 6. Nilai Sudut pada Gerakan Kaki Kanan Kedepan

\begin{tabular}{|c|c|c|c|c|}
\hline No & Bagian Robot & $\begin{array}{c}\text { Sudut Pada } \\
\text { Visualisasi ( }\end{array}$ & $\begin{array}{c}\text { Sudut Pada } \\
\text { Implementasi( }{ }^{\circ} \text { ) }\end{array}$ & $\begin{array}{c}\text { Error } \\
\mathbf{( \% )}\end{array}$ \\
\hline 1. & Hip Yaw Kanan & 0 & 0.5273 & 0.9985 \\
\hline 2. & Hip rol/ Kanan & 10 & 10.9296 & 9.2968 \\
\hline 3. & Hip Pitch Kanan & 35 & 35.2050 & 0.5859 \\
\hline 4. & Lutut Pitch Kanan & 0 & 0.7910 & 0.9978 \\
\hline 5. & Engkel Pitch Kanan & 15 & 16.2609 & 8.4062 \\
\hline 6. & Engkel Roll Kanan & 0 & 0.3730 & 0.9989 \\
\hline 7. & Hip Yaw Kiri & 0 & 0.2636 & 0.9992 \\
\hline 8. & Hip rol/ Kiri & 10 & 9.3878 & 6.1210 \\
\hline 9. & Hip Pitch Kiri & 10 & 11.1757 & 11.7578 \\
\hline 10. & Lutut Pitch Kiri & 0 & 0.8789 & 0.9975 \\
\hline 11. & Engkel Pitch Kiri & 15 & 14.8828 & 0.7812 \\
\hline 12. & Engkel Roll Kiri & 0 & 0.8789 & 0.9975 \\
\hline \multicolumn{5}{|r|}{} \\
\hline
\end{tabular}

Pada Tabel 6 menunjukkan nilai pengaturan sudut yang dilakukan pada media visualisasi dan implementasi. Dari perencanaan gerakan kaki kanan robot ke depan, dibuat pengaturan sudut 
pada bagian hip rol/ kanan, hip pitch kanan, engkel pitch kanan, hip rol/kiri, hip pitch kiri dan engkel pitch kiri (Gambar 4). Hal ini bertujuan untuk membuat pose dari gerakan robot kaki kanan ke depan. Proses pengukuran sudut implementasi robot dilakukan dengan cara membaca feedback posisi. Nilai error yang didapatkan untuk pengaturan hip roll kanan adalah 9.28\%. Sedangkan untuk nilai error yang didapatkan untuk pengaturan hip pitch kanan $0.58 \%$. Nilai error yang didapatkan untuk pengaturan engkel pitch kanan $8.4 \%$ Sehingga didapatkan nilai error rata-rata pada gerakan ini sebesar 3.58\%. Pada Gambar 15 berikut ini merupakan grafik dari perubahan sudut gerakan kaki kanan ke depan.

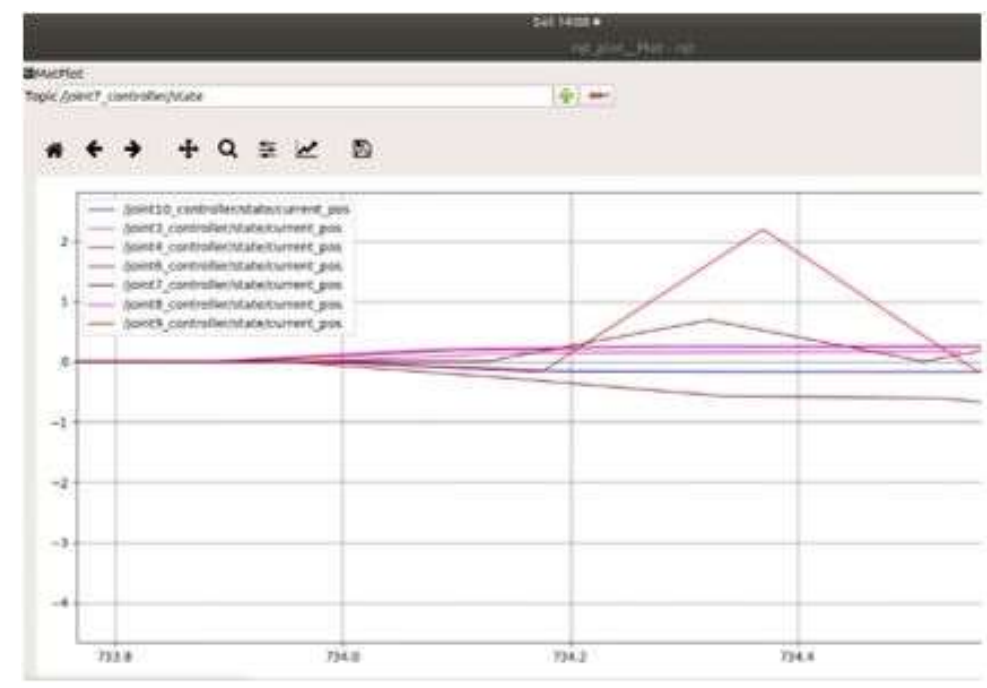

Gambar 15. Grafik Aktuator Robot Kaki Kanan di Depan

Pada Gambar 15 merupakan grafik yang menunjukkan perubahan sudut yang terbaca pada hip rol/ kanan dan hip rol/ kiri. Pada sumbu $X$ menunjukkan respon terhadap waktu dan sumbu y merupakan nilai sudut dalam satuan radian. Grafik tersebut terlihat perubahan dari kondisi robot diam menjadi bergerak condong ke kiri $\left(1 \mathrm{rad}=57.29^{\circ}\right)$. Nilai pembacaan pada engkel pitch kanan adalah 0.28 rad. Grafik tersebut menunjukkan implementasi pada masing-masing aktuator ketika terjadi perubahan dari kondisi robot diam menjadi bergerak kaki kanan maju.

\section{KESIMPULAN}

Berdasarkan pada pengujian yang telah dilakukan terhadap perencanaan sistem gerakan pada robot berkaki dua menggunakan ROS dan RViz dapat disimpulkan bahwa: Tingkat keberhasilan dari perencanaan gerakan ini memiliki rata rata error sebesar $1.8 \%$. Pada gerakan condong ke kiri memiliki rata-rata error sebesar $0.83 \%$. Kemudian untuk gerakan condong ke kanan memiliki rata-rata error sebesar $0.84 \%$. Sedangkan untuk gerakan mengangkat satu kaki memiliki rata-rata error sebesar $1.71 \%$. Selain itu, gerakan kaki kanan kedepan memiliki ratarata error sebesar 3.83\%. Error tersebut dapat terjadi karena faktor mekanik yang terdapat pada robot seperti backlash pada aktuator. Untuk selanjutnya sistem ini dapat diterapkan untuk pengembangan penilitian robot humanoid seperti meloncat, berlari dan sebagainya.

\section{UCAPAN TERIMA KASIH}

Terimakasih kepada Politeknik Elektronika Negeri Surabaya yang telah memberikan penulis beasiswa freshgraduate untuk program Pascasarjana Terapan. Terima kasih kepada Member 
Laboratorium Robotic and Intelligent Systems Center (RoISC) yang selalu memberikan dukungan dan doa kepada penulis untuk dapat menyelesaikan penulisan makalah ini.

\section{DAFTAR RUJUKAN}

Cashmore, M., Fox, M., Long, D., Magazzeni, D., Ridder, B., Carrera, A., Palomeras, N., Hurtós, N., \& Carreras, M. (2015). Rosplan: Planning in the robot operating system. IEEE Proceedings International Conference on Automated Planning and Scheduling, (pp. 333-341).

Arfaq, M., Dewanto, R. S., \& Pramadihanto, D. (2018). Fall Detection in T-FLoW Humanoid Robot:V-REP Simulation. IEEE International Electronics Symposium on Engineering Technology and Applications, (pp. 224-228). https://doi.org/10.1109/ELECSYM.2018. 8615463

Suhendra, T., \& Priyambodo, T. K. (2017). Analisis Perbandingan Algoritma Perencanaan Jalur Robot Bergerak Pada Lingkungan Dinamis. Indonesian Journal of Computing and Cybernetics Systems, 11(1), 21. https://doi.org/10.22146/ijccs.15743

Santos, J. M., Portugal, D., \& Rocha, R. P. (2013). An evaluation of 2D SLAM techniques available in Robot Operating System. In IEEE International Symposium on Safety, Security, and Rescue Robotics, (pp. 1-6). https://doi.org/10.1109/SSRR.2013.6719348

Balakirsky, S., \& Kootbally, Z. (2012). Usarsim/ros : A combined framework for robotic control and simulation. IEEE International Symposium on Flexible Automation. (pp. 101-108). https://doi.org/10.11509/isciesci.56.12_635

Fitri, N., \& Syafrudin, R. M. (2012). Perancangan Sistem Kendali Gerak Lengan Robot STMIK: STMIK GI MDP.

Prabowo, Y., Wisjhnuadji, T. W., \& Wibowo, A. A. (2013). Aplikasi pid pada robot line follower berbasis mikrokontroler at-8535. Jurnal Arsitron4, 4 (1), 15-22.

Allgeuer, P., Schwarz, M., Pastrana, J., Schueller, S., Missura, M., \& Behnke, S. (2018). A ROSbased Software Framework for the NimbRo-OP Humanoid Open Platform. In IEEE International Conference on Humanoid Robots (Humanoids).

Tomás Cunha, Pedro M Vieira2, Kevin Costa, and C. P. S. (2016). Looking for motor synergies in Darwin-OP biped robot. In IEEE International Conference On Robotics and Automation. (pp. 1776-1781).

Jalil, A. (2018). Robot Operating System (Ros) Dan Gazebo Sebagai Media Pembelajaran Robot Interaktif. ILKOM JurnalI/miah, 10 (3), 284-289. https://doi.org/10.33096/ilkom. v10i3.365.284-289 
Kam, H. R., Lee, S. H., Park, T., \& Kim, C. H. (2015). RViz: a toolkit for real domain data visualization. Telecommunication Systems, 60(2), 337 - 345.

Takaya, K., Asai, T., Kroumov, V., \& Smarandache, F. (2016). Simulation environment for mobile robots testing using ROS and Gazebo. IEEE International Conference on System Theory, Control and Computing, (pp. 96-101).

Kannan Megalingam, R., Ravi Teja, C., Sreekanth, S., \& Raj, A. (2018). ROS based Autonomous Indoor Navigation Simulation Using SLAM Algorithm. International Journal of Pure and Applied Mathematics, 118(7), 199-205.

Sokolov, M., Lavrenov, R., Gabdullin, A., Afanasyev, I., \& Magid, E. (2016). 3D modelling and simulation of a crawler robot in ROS/Gazebo. IEEE International Conference on Control, Mechatronics and Automation, (pp. 61-65). https://doi.org/10.1145/3029610.3029641

Robotis_MX-106T. (2020, May 20). Robotis e-Manual. Retrieved from Http://Emanual.Robotis.Com/Docs/En/Dxl/Mx/Mx-106/. 